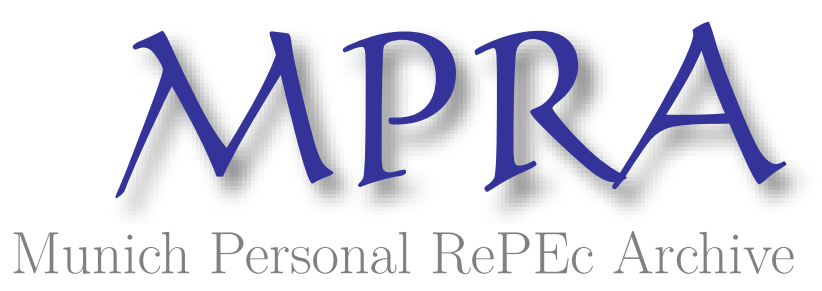

\title{
Regulating the International Audit Market and the removal of barriers to entry: The provision of non audit services by audit firms and the 2006 Statutory Audit Directive
}

Ojo, Marianne

Center for European Law and Politics, University of Bremen, Oxford Brookes University

14 November 2009

Online at https://mpra.ub.uni-muenchen.de/18624/

MPRA Paper No. 18624, posted 15 Nov 2009 15:10 UTC 


\begin{abstract}
From the responses received from the European Commission's consultation on control structures in audit firms and their consequences on the audit market, a consultation which was launched in November 2008, and whose deadline was scheduled for the end of February 2009, the role played by the facilitation of greater access to external financial capital as a means of increasing access to the audit market, hence opening up the market for the audit of international companies to more suppliers, and encouraging new market players, was acknowledged. However, this factor on its own, coupled with the need to amend current rules on the control of audit firms, namely through a relaxation of the rules - beyond that which is currently permitted under Article 3 of the 2006 Statutory Audit Directive, was not considered to be the most important source of impediment to the emergence of new players. Other further possible catalysts, both on the supply side (namely auditors) and the demand side (companies), were also considered vital to efforts aimed at encouraging more players in gaining access to the international audit market.
\end{abstract}

This paper will focus on greater access to external financial capital - as a means of lowering barriers to the international audit market. In arriving at the conclusion that the benefits associated with the external investor model outweigh the possible risks it generates, the paper not only considers theories on managerial behaviour and ownership structure, but also gives attention to the safeguards for audit independence as listed under the 2002 Statutory Auditors' Independence in the EU: A Set of Fundamental Principles, and the 2006 Statutory Audit Directive. It will also consider why, in view of the limitations and restrictions placed on audit firms, with particular reference to the Sarbanes Oxley Act of 2002, actions aimed at encouraging new market players at EU level, whilst ensuring that auditors' independence and audit quality are not compromised, would also require a consideration of an international dimension of issues involved in lowering barriers to entry.

Key words: 2006 Statutory Audit Directive; non audit services; regulation; audit concentration; governance; audit independence; Sarbanes Oxley Act. 


\title{
Regulating the International Audit Market and the Removal of Barriers to Entry: The Provision of Non Audit Services by Audit Firms and the 2006 Statutory Audit Directive
}

\author{
Marianne Ojo ${ }^{1}$
}

\section{Introduction}

The role played by audit markets in determining the degree of financial stability is attributed to the level of audit concentration which currently exists in the financial markets. Since the demise of Arthur Andersen, regulators have become increasingly more aware of the systemic consequences which could result in the event of a major audit firm's sudden exit from the audit market. The loss of one of such audit firms, it is acknowledged ${ }^{2}$, would not only have " a serious impact on public confidence for audit services" but also had the potential to trigger a "crisis of confidence" in financial markets - given the prominent role assumed by auditors in the company-investor relationship. Further, a market where high audit concentration exists has the following disadvantages, namely: The likelihood that audit incentives could be impaired owing to the Big Four's awareness of their dominant position in the market and a "too big to fail policy' which the government might be compelled to implement; the limited impact of a threat of a loss of reputation (major audit firm's reputation) ${ }^{3}-$ this situation would have been different if a high level of competition existed in such a market; lower quality of audits.

As a result, the need to provide external investors with greater access to the international audit market, reduce the market share retained by the Big Four audit firms and ensure that present market structure does not deteriorate further than its present state, the importance of implementing measures at European level - measures which would not only facilitate the entry of new market players, but also preserve the level of audit quality and audit independence, have been re iterated. ${ }^{4}$ The main areas which constituted the focus of consideration during a recent consultation exercise ${ }^{5}$ included: The need to ensure greater access to the international audit market, the need for greater integration within the European market - as well as facilitating greater integration within audit firms and networks, the need to consider changes to the rules which govern control structures and, the preservation of audit independence 6 . From these topics, greater consideration will be given to the need for greater

\footnotetext{
${ }^{1}$ Research fellow, Center for European Law and Politics (ZERP), University of Bremen; Graduate Teaching Associate, Oxford Brookes University.

${ }^{2}$ See "Consultation on Control Structures in Audit Firms and their Consequences on the Audit Market" at page 7 < http://ec.europa.eu/internal_market/auditing/docs/market/consultation2008/summary_report_en.pdf > (last visited 3 November 2009)

${ }^{3}$ See also J Bigus and R Zimmerman, 'Non Audit Fees, Market Leaders and Concentration in the German Audit Market: A Descriptive Analysis' (2008)International Journal of Auditing Vol 12 at page 174

${ }^{4}$ See statement by $\mathrm{C}$ McCreevy 'International audit market: consultation respondents recognise need to remove barriers to entry' <

http://europa.eu/rapid/pressReleasesAction.do?reference=IP/09/1139\&format=HTML\&aged=0\&language=EN\& guiLanguage=en>

${ }^{5}$ This was carried out by the Directorate General for Internal Market and Services . Having been launched in November 2008, the deadline for the receipt of responses to the exercise was February 2009.

${ }^{6}$ The need for additional measures which would safeguard independence at European level and means whereby such safeguards could be consolidated, were also given due consideration. See < http://ec.europa.eu/internal_market/auditing/docs/market/consultation2008/summary_report_en.pdf $>$ at page 4
} 
integration within the European market (and efforts which have been undertaken so far to promote such an aim), the need to consider changes in the rules relating to control structures and audit independence. These topics will be considered against the background of developments and progress in relation to the Statutory Audit Directive, and how a change in the rules on control structures affect audit independence. In relation to audit independence, focus will be given to non audit services (NAS) - this being one of the factors which have been identified as having the potential to impair auditors' independence. ${ }^{7}$

The general response to the consultation topic involving greater introduction of new market entrants at international level indicated that respondents favoured such an initiative - whilst highlighting the importance of sustaining high level audit quality. ${ }^{8}$ Furthermore, those respondents who indicated that the problem (relating to the need for greater access to the international audit market) was that of a lack of choice, generally emphasized that this did not imply a lack of competition. ${ }^{9}$

This paper will focus on the facilitation of greater access to external financial capital as a means of increasing access to the audit market - even though other catalysts which could encourage more players to gain access to the international audit market exist. Catalysts on the supply side include: ${ }^{10}$ the need for greater harmonisation through a harmonisation of the independence rules and other ethical requirements for auditing, the application at EU level of "more restrictive rules" on the provision of non audit services which could enable smaller firms to be more competitive (since the Big Four who provide a wide range of non audit services may be prohibited from placing bids in particular situations); consideration that harmonisation of rules associated with the limitation of auditors' liability would provide an incentive for audit firms to access the international market; and the adoption of international auditing standards to facilitate harmonisation within the EU audit market. The sections within this paper are structured as follows: Section one will commence with an analysis which traces developments and legislation which have emerged in the EU in response to the collapse of Enron. Such an analysis will incorporate a description and an assessment of the extent to which prohibition of non audit services by audit firms and the disclosure of audit remuneration has occurred in Germany and in the UK. This will then lead to a discussion on audit independence within the context of the controversial debate on whether or not the provision of non audit services generates more benefits than risks for the audit of financial statements. The next section then considers not only how a more integrated single audit market at European level can be achieved, but also why this is necessary. Within this framework, the 2006 Statutory Audit Directive will be introduced.

The section which then follows will elaborate on how an amendment to the rules on the control of audit firms, beyond the scope which is presently prescribed by Article 3 of the Statutory Audit Directive, could be achieved. Further a consideration which involves not only the drawbacks of such a proposal, but other possible alternatives, will be undertaken. Arguments in favour of and against a majority of external investors will then be considered in the sixth section of the paper. The seventh section will focus on the impact which could be generated (by an amendment to ownership rules and external capital), on audit independence,

\footnotetext{
${ }^{7}$ Other situations where the impairment of audit independence could occur, as identified by Quick and Rasmussen include personal interaction, financial interest and personal relationships. See R Quick and B Warming-Rasmussen, 'Auditor Independence and the Provision of Non Audit Services: Perceptions by German Investors'(2009) International Journal of Auditing Volume 13 at page 142

${ }^{8}$ See "Consultation on Control Structures in Audit Firms and their Consequences on the Audit Market" $<$ http://ec.europa.eu/internal_market/auditing/docs/market/consultation2008/summary_report_en.pdf > at page 7

9 ibid at page 6

${ }^{10} \mathrm{ibid}$ at pages $16-19$
} 
as well as proposed safeguards which should operate to counter risks posed by the existence of external investors.

Whether more stringent regulations on audit liability should be introduced (or not), will constitute the focus of consideration in the penultimate section. This would facilitate a discussion on principles and rules based approaches to regulation and also provide an illustration of each approach - with particular reference to Sarbanes Oxley's rules based approach to regulation and whether the Sarbanes Oxley Act (SOX) is actually remedying or aggravating the problem which it is supposed to cure. The concluding section draws on how the 2006 Statutory Audit Directive, along with other proposals advanced during the course of the paper, could help lower the barriers to entry within the audit market - whilst ensuring that audit quality is not undermined and that audit independence is not compromised.

2. Legislative developments which have taken place to improve the auditor's independence

Audit related legislation which existed prior to the Enron scandal include the Fourth Council Directive, ${ }^{11}$ the Seventh Council Directive ${ }^{12}$ and the Eighth Council Directive ${ }^{13}$. In 2002, the European Commission issued a Recommendation of a set of fundamental principles regarding the statutory auditor's independence: "Statutory Auditors' Independence in the EU: A Set of Fundamental Principles" . ${ }^{14}$ The Recommendation considered two key independence issues raised by the collapse of Enron, namely "provision of additional services" by auditors and their "employment with the audit client. ${ }^{15}$ The principles also provided details on the scope and responsibility of statutory auditors, and stipulated systems of safeguards, independence threats and risks. ${ }^{16}$ In view of other financial scandals, a revised Eight Directive ${ }^{17}$ was proposed. However the Eight Council Directive has been repealed by the 2006 Statutory Audit Directive ${ }^{18}$ which also amends the Fourth and Seventh Council directives.

In Germany, these developments were responded to with the imposition of additional restrictions in the German Commercial Code. ${ }^{19}$ Whilst involvement in the retention of the client's accounting records and the preparation of its annual financial statements had been previously prohibited, the prohibition of "provision of legal or tax advisory services in the

\footnotetext{
${ }^{11}$ Council Directive 78/660/EEC which imposes the requirement that all companies under the Directive be audited by a qualified professional

${ }^{12}$ Council Directive 83/349/EEC

${ }^{13}$ Which having set out conditions for the approval of persons responsible for carrying out statutory audits, was criticised for failing to provide specific guidance on auditor independence.

${ }^{14}$ See 'Auditing: Commission issues Recommendation on independence of statutory auditors' < http://europa.eu/rapid/pressReleasesAction.do?reference=IP/02/723\&format=HTML\&aged=1\&language=EN\&g uiLanguage $=e n>$ (last visited 4 November 2009)

15 ibid

${ }^{16}$ See "Statutory Auditors' Independence in the EU: A Set of Fundamental Principles"< http://www.iasplus.com/resource/euaudit.pdf>

${ }^{17}$ For further information on the revised Eight Directive and a comprehensive comparison between it and the Sarbanes Oxley Act, see C Strohm, United States and European Union Audit Independence Regulation: Implications for Regulators and Auditing Practice 2006 DUV

18 DIRECTIVE 2006/43/EC OF THE EUROPEAN PARLIAMENT AND OF THE COUNCIL

of 17 May 2006 on statutory audits of annual accounts and consolidated accounts

${ }^{19}$ See R Quick and B Rasmussen 'Auditor Independence and the Provision of Non Audit Services: Perceptions by German Investors'(2009) International Journal of Auditing Volume 13 at page 145
} 
financial statements which were to be audited, constituted part of additional restrictions which were added in December 2004. ${ }^{20}$

Furthermore, the amended Code, with particular reference to $\S \S 285$ I No 17, 314 I No 9 HGB stipulates the requirement that listed companies disclose audit and non audit fees paid to them as from the financial year $2005 .^{21}$

The debates revolving round the provision by audit firms, of non audit services have proved more controversial in the UK. Whilst companies, accountancy firms and even the ACCA ${ }^{22}$ have put forward arguments in support of the need to provide non audit services ${ }^{23}$, the UK Treasury Select Committee in its Ninth Report ${ }^{24}$ stated that it believed that ..."investor confidence and trust in audits would be enhanced by a prohibition on audit firms conducting non audit work for the same company"... and recommended that a consultation should be carried out by the Financial Reporting Council in relation to their proposal. ${ }^{25}$

According to the Financial Reporting Council (FRC), who in response to the Select Committee's recommendation issued a consultation paper through the Auditing Practices Board, the views of "certain representatives of the investor community" and "particular commentators" 26 were instrumental in the UK Treasury Select Committee's decision to recommend a consultation on the prohibition of non audit services. ${ }^{27}$

Such a proposal by the Select Committee and the recommendation that the FRC consult on the proposal, signifies a change in the approach to non audit services - having due regards to the early developments which took place in the aftermath of Enron's collapse. Following Enron's collapse, the Coordinating Group on Audit and Accounting (CGAA) was established to review the UK's arrangement for audit and accountancy. A complete prohibition of the provision of non audit services (by firms conducting non audit work for the same company)

\footnotetext{
${ }^{20}$ ibid

${ }^{21}$ See J Bigus and R Zimmerman, 'Non Audit Fees, Market Leaders and Concentration in the German Audit Market: A Descriptive Analysis' (2008)International Journal of Auditing Vol 12 at page 160. The study carried out by Bigus and Zimmerman benefited from this amended in that previously unaccounted questions related to audit and non audit fees are now subject to disclosure - hence facilitating the study - which is the first to present the weight of non audit fees in the audit market in Germany to international observers. See ibid

${ }^{22}$ Association of Chartered Certified Accountants; The ACCA is also of the opinion that an outright separation of audit and non audit services would neither be feasible or preferred and that some services are closely related to audit - whilst insight into the audit firm adds benefits of quality and efficiency which businesses would not want to forego. Also see I Welch, "Should Cross Selling of Non Audit fees be Banned? FRC Consults on MPs Recommendation" 12 October 2009 < http://blogs.accaglobal.com/business_blog/2009/10/heading-tocome.html>

${ }^{23}$ Arguments put forward revolve round a broader debate which views audit training as a crucial aspect of being an accountant and the fact an outright prohibition of non audit services to audit clients could result in audits being considered as a "specialist activity". See I Welch, "Should Cross Selling of Non Audit fees be Banned? FRC Consults on MPs Recommendation" 12 October 2009 < http://blogs.accaglobal.com/business_blog/2009/10/heading-to-come.html>

${ }^{24}$ Treasury Ninth Report, 'Banking Crisis: reforming corporate governance and pay in the City' May $2009<$ http://www.publications.parliament.uk/pa/cm200102/cmselect/cmtreasy/758/2070213.htm> (last visited 10 Novemeber 2009)

${ }^{25}$ See 'APB issues a Consultation Paper on audit firms providing non-audit services to listed companies that they audit' < http://www.frc.org.uk/apb/press/pub2125.html> (last visited 10 November 2009)

${ }^{26}$ Who expressed doubts concerning the auditor's ability to sustain independence whilst providing non audit services

${ }^{27}$ See I Welch, "Should Cross Selling of Non Audit fees be Banned? FRC Consults on MPs Recommendation" 12 October 2009 < http://blogs.accaglobal.com/business_blog/2009/10/heading-to-come.html>
} 
was excluded at the time - with the CGAA deciding that tougher measures were required to ensure that auditors were not only independent, but perceived to be independent. ${ }^{28}$

In early 2003, the government decided that the responsibilities for setting standards for the integrity, objectivity and independence of audits should be transferred from the professional bodies to the Auditing Practices Board (part of the FRC). ${ }^{29}$ Consequently, these standards were issued by the APB in 2004. ${ }^{30}$ The Companies (Disclosure of Auditor Remuneration) Regulations 2005 came into force on the $1^{\text {st }}$ of October 2005. According to the legislation, companies are required "to disclose in the notes to the annual accounts the remuneration paid to a company's auditors for non audit services split between:

Any remuneration receivable by the company's auditors for the auditing of the accounts, and

Any remuneration for the supply of other services to the company or its associates ${ }^{31}$

\section{Audit Independence and Non Audit Services (NAS)}

According to the 2002 Principles establishing a set of fundamental principles, ${ }^{32}$

"The requirement that a Statutory Auditor should be independent addresses both:

- $\quad$ Independence of mind, i.e. the state of mind which has regard to all considerations relevant to the task in hand, but no others; and

Independence in appearance, i.e. the avoidance of facts and circumstances which are so significant that a reasonable and informed third party would question the Statutory Auditor's ability to act objectively."

\section{According to Article 22 paragraph 2 of the Statutory Audit Directive ${ }^{33}$}

Member States shall ensure that a statutory auditor or an audit firm shall not carry out a statutory audit if there is any direct or indirect financial, business, employment or other relationship

— including the provision of additional non-audit services - between the statutory auditor, audit firm or network and the audited entity from which an objective, reasonable and informed third party would conclude that the statutory auditor's or audit firm's independence is compromised.

If the statutory auditor's or audit firm's independence is affected by threats, such as self-review, self-interest, advocacy, familiarity or trust or intimidation, the statutory auditor or audit firm must apply safeguards in order to

\footnotetext{
${ }^{28}$ See paragraphs 4.1 and 4.2 of Auditing Practices Board Ethical Standards: Consultation on Audit Firms Providing Non Audit Services to Listed Companies that they Audit 'CGAA Review of the Arrangements for Audit and Accountancy in the UK' at page 9. Furthermore, it was particularly recommended that whilst UK requirements should continue to apply a principles rather than rules based approach to regulation, that clearer and tougher safeguards would be required to ensure that the joint provision of audit and non audit services would not compromise audit independence "in fact or appearance" and that this was to be achieved through:

Regulation of audit firms by: Independent setting of auditor independence standards; tougher requirements governing the supply of NAS to audit clients; and emphasis within the monitoring system on the application of these requirements in the major audit firms. See paragraph $4.3 \mathrm{ibid}$.

${ }^{29}$ Ibid at page 10

${ }^{30}$ ibid

31 ibid at page 19

${ }^{32}$ See Statutory Auditors' Independence in the EU: A Set of Fundamental Principles

$<$ http://www.iasplus.com/resource/euaudit.pdf $>$ at page 22

${ }^{33}$ DIRECTIVE 2006/43/EC OF THE EUROPEAN PARLIAMENT AND OF THE COUNCIL

of 17 May 2006 on statutory audits of annual accounts and consolidated accounts
} 
mitigate those threats. If the significance of the threats compared to the safeguards applied is such that his, her or its independence is compromised, the statutory auditor or audit firm shall not carry out the statutory audit.

The provision of non audit services by audit firms has generated many controversial debates over the years. Questions related to such debates revolve round issues concerning whether the provision of non audit services by audit firms really impairs independence. Further, if the provision of NAS do indeed impair audit independence, to what extent is an auditor's independence compromised and do the disadvantages related to such an impairment actually outweigh the benefits derived by audit firms in their provision of NAS?

The figures below, as published by the Financial Director, reveal a steep decline in the ratio of non audit to audit fees in listed companies since the collapse of Enron.

\begin{tabular}{|l|c|c|c|c|c|c|}
\hline All figures in $\mathrm{fm}$ & 2002 & 2003 & 2004 & 2005 & 2006 & 2008 \\
\hline Audit fees & 238 & 275 & 326 & 371 & 402 & 530 \\
\hline $\begin{array}{l}\text { Non-audit services } \\
\text { (incl. services pursuant } \\
\text { to legislation) }\end{array}$ & 454 & 357 & 328 & 329 & 312 & 379 \\
\hline $\begin{array}{l}\text { Non-audit fees as \% of } \\
\text { audit fees }\end{array}$ & $191 \%$ & $130 \%$ & $100 \%$ & $89 \%$ & $78 \%$ & $71 \%$ \\
\hline
\end{tabular}

Source: ${ }^{34}$

Arguments advanced in favour of the provision of non audit services by audit firms

Whilst the debate on the provision of non audit services has proved contentious ${ }^{35}$, arguments in favour of the provision of non audit services by audit firms as set out in the APB's Consultation Document ${ }^{36}$ are as follows:

- That the provision of non audit services provides a valuable means of a company benefiting from external expertise, hence enabling management to focus on key business activities

- Auditors have the confidence of management and already know the company well and do not require the same degree of briefing and oversight as would be required by firms who are unfamiliar with the company. This could result in benefits linked to cost, quality and consistency - which in turn would benefit shareholders

\footnotetext{
${ }^{34}$ Auditing Practices Board Ethical Standards: Consultation on Audit Firms Providing Non Audit Services to Listed Companies that they Audit page16. In 2005/06, a collaboration between the Financial Reporting Council and the then Department of Trade and Industry resulted in an investigation into the level of competition and choice in the market for the provision of audit services. It was observed that the provision of non audit services by the company's auditor could hinder competition and choice in relation to the provision of audit services. See page 20 of Auditing Practices Board Ethical Standards: Consultation on Audit Firms Providing Non Audit Services to Listed Companies that they Audit

${ }^{35}$ For further literature on such debates, see R Quick and B Warming-Rasmussen, 'Auditor Independence and the Provision of Non Audit Services: Perceptions by German Investors (2009) International Journal of Auditing (13) 141-162 and M Ezzamel, DR Gwilliam and KM Holland, 'The Relationship between Categories of NonAudit Services and Audit Fees: Evidence from UK Companies' (2002) International Journal of Auditing (6) 1335

${ }^{36}$ Ethical Standards: Consultation on Audit Firms Providing Non Audit Services to Listed Companies that they Audit, see pages 6 and 7. For information relating to arguments advanced by accountancy firms who support the provision of non audit services to audit clients see page 7 .
} 
- That corporate regime already ensures that non audit services are purchased without the fear that audit independence would be compromised

4. Towards a more integrated single audit market at European level

The 2006 Statutory Audit Directive ${ }^{37}$ acknowledges the importance of cooperation between member states at European level if the objectives of the Directive are to be realised.

Paragraph 32 of the Preamble reads:

Since the objectives of this Directive - namely requiring the application of a single set of international auditing standards, the updating of the educational requirements, the definition of professional ethics and the technical implementation of the cooperation between competent authorities of Member States and between those authorities and the authorities of third countries, in order further to enhance and harmonise the quality of statutory audit in the Community and to facilitate cooperation between Member States and with third countries so as to strengthen confidence in the statutory audit — cannot be sufficiently achieved by the Member Statesand can therefore, by reason of the scale and effects of this Directive, be better achieved at Community level, the Community may adopt measures, in accordance with the principle of subsidiarity as set out in Article 5 of the Treaty. In accordance with the principle of proportionality, as set out in that Article, this Directive does not go beyond what is necessary in order to achieve those objectives.

A single audit market at European level would also facilitate the introduction of audit liability caps at EU level. ${ }^{38}$ The introduction of liability caps would not only reduce the likelihood of a large sized audit firm's failure, but could also reduce market concentration in audit markets. According to the responses which were received in relation to the topic on greater integration within the European market, respondents highlighted the urgency in establishing a single audit market at European level. In doing so, they pointed out factors which have served as sources of impediment to such a goal, namely, lack of sufficiently integrated legal framework and supervisory structures in the EU. ${ }^{39}$

The effectiveness of proposals aimed at reducing market barriers depends on a number of factors - amongst which include the demand for audits in particular jurisdictions. The demand for audits in jurisdictions where capital market based transactions occur at a higher volume, jurisdictions such as that of the UK and the US could be considered to be higher than that of jurisdictions such as Germany and Italy. Audit markets with relatively few large clients are referred to as thin markets. ${ }^{40}$ Germany has been classed as having a relatively thin market as relatively few companies are public limited companies (AGs) - hence audit concentration is likely to be high. Having considered a number of factors ${ }^{41}$ including the long tradition of historical cost accounting and limited disclosure - from which they inferred that accountants and auditors are less familiar with fair value accounting than in the UK or the US, and that

\footnotetext{
${ }^{37}$ DIRECTIVE 2006/43/EC OF THE EUROPEAN PARLIAMENT AND OF THE COUNCIL of 17 May 2006 on statutory audits of annual accounts and consolidated accounts

${ }^{38}$ For more information on audit liability caps, see M Ojo 'Proposals For a New Audit Liability Regime in Europe' and 'Limiting Audit Firms' Liability: A Step in the Right Direction? (Proposals For a New Audit Liability Regime in Europe Revisited) The Accountant July 2009 Issue 6068

${ }^{39}$ Consultation on Control Structures in Audit Firms and their Consequences on the Audit Market" at page $7<$ http://ec.europa.eu/internal_market/auditing/docs/market/consultation2008/summary_report_en.pdf>

${ }^{40}$ See M Ojo 'The Role of the External Auditor in Bank Regulation and Supervision: A Comparative Analysis between the UK, Germany, Italy and the US (2008) VDM

${ }^{41}$ Such factors include the absence of market values, the fact that fair value accounting necessitates greater "know-how" in valuation techniques than historical accounting. See J Bigus and R Zimmerman, 'Non Audit Fees, Market Leaders and Concentration in the German Audit Market: A Descriptive Analysis' (2008)International Journal of Auditing Vol 12 at page 161
} 
market entry may be less difficult than in the UK and the US, Bigus and Zimmerman initially concluded that a lower degree of market concentration could be expected in Germany than in the USA and the UK. However their findings indicated a somewhat different result. ${ }^{42}$

Furthermore, Bigus and Zimmerman argue that in introducing audit liability caps, consideration should be had towards the possibility that audit incentives may be impaired. ${ }^{43}$ As additional measures, actions aimed at the consolidation of competition, actions such as those which would make market entry much easier, have been proposed. ${ }^{44}$ Such actions (apart from the introduction of low audit liability caps), include the enactment of less complex and less rigid regulations on accounting and auditing. ${ }^{45}$ Means of achieving such an aim, as recommended, include a change from fair value accounting to historical cost accounting. ${ }^{46}$ This option is provided given their acknowledgement of the fact that low liability caps may not necessarily deter market concentration. ${ }^{47}$

In relation to audits of most of the international companies and according to responses obtained from the consultation, the actual choice available is greater than those provided by the Big Four and is inclusive of services which can be offered by mid tier audit firms. ${ }^{48}$ However, owing to lack of recognition of the capabilities of such mid tier audit firms who are able to work in the international audit market but are presently finding it difficult to "break into" the market, such firms are placed at a disadvantage. ${ }^{49}$

5. Amendment to rules on the control of audit firms to allow for capital investments from external investors, beyond what is currently prescribed by Article 3 of the Statutory Audit Directive.

\section{The Statutory Auditors' Independence in the EU: A Set of Fundamental Principles}

imposed a requirement that the majority of voting rights in a firm be held by qualified auditors - these being permitted to undertake statutory audits in the EU.

\footnotetext{
${ }^{42}$ See ibid; The results of their findings indicate a lower level of concentration in the UK and the USA than in Germany, whilst Switzerland appeared to have a higher level of concentration than Germany. See also page 175 ibid where results also indicated that Germany and the UK have comparable levels of concentration in their audit markets whilst concentration levels are higher in Switzerland (than in Germany) and lower in the USA (than in Germany)

${ }^{43}$ J Bigus and R Zimmerman, 'Non Audit Fees, Market Leaders and Concentration in the German Audit Market: A Descriptive Analysis' (2008)International Journal of Auditing Vol 12 at page 174

${ }^{44}$ ibid at pages $174-175$

45 ibid at 175

${ }^{46}$ ibid

47 ibid

${ }^{48}$ See 'Summary Report: Consultation on Control Structures in Audit Firms and their Consequences on the Audit Market' $<$ http://ec.europa.eu/internal_market/auditing/docs/market/consultation2008/summary_report_en.pdf $>$ at page 6 ${ }^{49}$ ibid
} 
Section 4.3 which deals with the Statutory Auditor's Overall Safeguards, in relation to the ownership and control over audit firms, provides under section 4.3.1 that: ${ }^{50}$

"If the Statutory Auditor is an Audit Firm, at least the majority of the firm's voting rights (50\% plus one vote) must be held by persons who are authorised to perform Statutory Audits within the European Union (statutory auditors). The Statutory Auditor's legal statutes should contain provisions to ensure that a non-auditor owner could not gain control over the Audit Firm."

Whilst Chapter II Article 3(4) of the 2006 Statutory Audit Directive reinforces the requirement of majority voting rights ${ }^{51}$, Article 1(6) reflects a more relaxed and flexible approach:

(6) Audit qualifications obtained by statutory auditors on the basis of this Directive should be considered equivalent. It should therefore no longer be possible for Member States to insist that a majority of the voting rights in an audit firm must be held by locally approved auditors or that a majority of the members of the administrative or management body of an audit firm must be locally approved.

A modification in ownership rules would provide non Big 4 audit firms with greater access to compete in the financial market. Furthermore, less stringent ownership rules would not only facilitate greater integration between audit firms on a cross border basis, but also, greater and speedier access to capital could also limit liability risks and facilitate the re capitalisation of a firm ${ }^{52}$

From the results obtained, $43 \%$ (the majority) indicated their support of a change in the present rules relating to the control of audit firms. ${ }^{53}$ Furthermore, results indicated that in order to facilitate capital investments from external investors, rules on the control of audit firms should be amended. ${ }^{54}$ Various options proposed in relation to how such an amendment could occur include: ${ }^{55}$ (i) Consideration of an external investor model based on voting rights the majority of these now being acquired by non auditors. This could be facilitated through a prohibition on any measures which could serve as a source of impediment to external investors who may wish to acquire majority shareholdings and voting rights in a firm; (ii) Consideration of a "multi disciplinary practice model" which is based on the provision of capital by auditors and members of other regulated professions - again with the restriction that qualified auditors would not be able to acquire the majority of the capital; (iii) Consideration of state owned bodies functioning under the same rules and control structure as

\footnotetext{
${ }^{50}$ Statutory Auditors' Independence in the EU: A Set of Fundamental Principles, <http://www.iasplus.com/resource/euaudit.pdf > at page 8 of 54

${ }^{51}$ Article 3(4)(c) of the Chapter reads: "a majority - up to a maximum of $75 \%$ - of the members of the administrative or management body of the entity must be audit firms which are approved in any Member State or natural persons who satisfy at least the conditions imposed by Articles 4 and 6 to 12. Member States may provide that such natural persons must also have been approved in another Member State. Where such a body has no more than two members, one of those members must satisfy at least the conditions in this point"

${ }^{52}$ See 'Summary Report: Consultation on Control Structures in Audit Firms and their Consequences on the Audit Market'

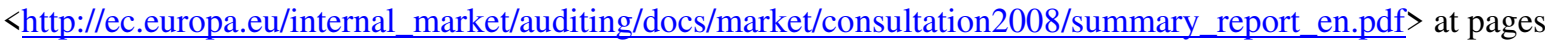
11 and 12

${ }^{53}$ see ibid <http://ec.europa.eu/internal_market/auditing/docs/market/consultation2008/summary_report_en.pdf $>$ at page $10 ; 33 \%$ of the respondents were undecided whilst $24 \%$ were against any change

${ }^{54}$ See ibid at page 8

55 ibid at page 11
} 
commercial audit firms. Identified disadvantages attributed to a state owned model include its remunerative attracting power - that is, the likelihood that its level of remuneration may not meet that of the private sector. Furthermore, political concerns (relating to such a model) attributed to exposure of public funding were reiterated by some of the respondents; (iv) A hybrid model consisting of a collaboration between external investors and/or funding from the taxpayer; and finally (v) The extension of majority ownership to embrace auditors and audit firms from third countries who are subject to the same degree of supervision as those firms within the EU - and also providing means of ensuring that audit quality is sustained on a global level.

State control and state intervention are proposed as alternatives in the event that a regulator does not wish to relax regulations in order to facilitate market entry. ${ }^{56}$ However the difficulties associated with state control as revealed during the recent financial crises, are also highlighted. ${ }^{57}$ Furthermore, it is contended that even if state agent were able to obtain adequate resources and retain highly qualified employees, and even if they were not pursuing their own interests, the likelihood that accounting scandals would not be detected on time, would still exist. ${ }^{58}$

Even though it was generally agreed by the respondents that there was a need to make international audit market more accessible to external investors and reduce the market share retained by Big Four audit firms, totally lifting all ownership rules, in the opinion of many respondents, was considered not to be an optimal idea. ${ }^{59}$ This was attributed to the fact that the retention of some restrictions on the governance of audit firms is still considered necessary as a means of fostering supervision and accountability. ${ }^{60}$

\section{Arguments in favour of and against a majority of external investors}

Arguments against a majority of external investors include: ${ }^{61}$ The likelihood of increased costs of capital since equity investors could require compensating returns for their acceptance of greater risks, the likelihood that external investments could be deterred- owing to an unlimited liability regime, the possibility that a reduction in choice and impeded competition could actually occur - owing to breach of independence rules and conflicts of interests generated where such external investors are involved in other investments and business relationships.

Impact of an amendment of ownership rules and external capital on auditor independence

Concern was expressed amongst most of the respondents to the consultation that audit quality would not only be impaired, but that audit independence would also be compromised. ${ }^{62}$ These

\footnotetext{
${ }^{56}$ See J Bigus and R Zimmerman, 'Non Audit Fees, Market Leaders and Concentration in the German Audit Market: A Descriptive Analysis' (2008)International Journal of Auditing Vol 12 at page 175

${ }^{57}$ ibid

58 ibid

${ }^{59}$ See 'Summary Report: Consultation on Control Structures in Audit Firms and their Consequences on the Audit Market'

$<$ http://ec.europa.eu/internal_market/auditing/docs/market/consultation2008/summary_report_en.pdf $>$ at page 11

60 ibid

61 ibid at page 12

${ }^{62}$ Further concerns were also indicated in relation to the negative consequences that an amendment could generate on public perception of the independence of the audit profession. ibid at page 13
} 
concerns were partly attributed to their consideration that the risk of the management of a firm, based on profit margins rather than on audit quality, would be introduced. ${ }^{63}$

More dispersed ownership is expected to result in greater reliance being placed on the audit as a mechanism of governance. ${ }^{64}$ Therefore it could be argued that the corresponding move in placing a greater reliance on audits, although this might be more costly, should help alleviate concerns related to audit independence. Furthermore, as argued by Jensen and Meckling, even though dispersed ownership would presuppose higher probabilities that managers would wish to further self interests at the expense of owners, they argue that such managers are not only aware of the resulting increased agency costs, but also expected to limit such costs and would respond by committing themselves to more extensive audits. ${ }^{65}$

7. Proposed safeguards which should operate to counter risks posed by the existence of external investors include: ${ }^{66}$

- examples of safeguards proposed by respondents in relation to the governance of audit firms (The extension of ethical guidance to owners who are not auditors, modification of governance rules for audit firms)

- $\quad$ examples of safeguards which relate to capital and voting rights (prohibition of capital provision to non auditors)

- examples of safeguards based on actions taken by the regulator

It is difficult to draw a conclusion on whether additional safeguards should be prescribed with a change in ownership rules - given the fact that sufficient safeguards appear to be in place. Safeguards are provided for under section 4 of the 2002 Set of Fundamental Principles ${ }^{67}$ and under Article 22 of the 2006 Statutory Audit Directive.

\footnotetext{
${ }^{63}$ ibid

${ }^{64}$ N O'Sullivan and SR Diacon, 'Impact of Ownership, Governance and Non Audit Services on Audit Fees: Evidence from the Insurance Industry'(2002) International Journal of Auditing Volume 6 at page 95; also see P Chan, M Ezzamel, and D Gwilliam, 'Determinants of audit fees for quoted U.K. companies' (1993) Journal of Business Finance \& Accounting, 20, pp. 765-786.

${ }^{65}$ N O'Sullivan and SR Diacon, 'Impact of Ownership, Governance and Non Audit Services on Audit Fees: Evidence from the Insurance Industry'(2002) International Journal of Auditing Volume 6 at page 95; and MC Jensen and WH Meckling , 'Theory of the firm: managerial behaviour, agency costs and ownership structure' (1976) Journal of Financial Economics, 3, pp. 305-360.

${ }^{66}$ See 'Summary Report: Consultation on Control Structures in Audit Firms and their Consequences on the Audit Market'at pages 15 and 16

${ }^{67}$ See 'COMMISSION RECOMMENDATION of 16 May 2002 Statutory Auditors' Independence in the EU: A Set of Fundamental Principles' $<$ http://eurlex.europa.eu/LexUriServ/LexUriServ.do?uri=OJ:L:2002:191:0022:0057:EN:PDF (last visited 11 November 2009)
} 
8. More Stringent Regulations or Consideration of the Need to Facilitate Market Entry?: Rule based and Principles Based Approaches to Regulation

Even though work is required on the legal framework and supervisory structures at European level, other global related issues need to be considered. Financial scandals such as that of Enron have resulted in more stringent audit liability measures in the form of higher corporate governance and auditing standards. ${ }^{6}$ In attempting to address the issues related to audit independence, namely the provision of non audit services, the Sarbanes Oxley Act of 2002 (SOX) with its more detailed and rules based approach to regulation has placed further restrictions on transactions carried out on the international audit market scene and in doing so, raised the barriers to entry for potential market participants.

According to the Commission Recommendation of 2002, "Statutory Auditors' Independence in the EU: A Set of Fundamental Principles" ${ }^{\text {"9 }}$

\begin{abstract}
A principles-based approach to statutory auditors' independence is preferable to one based on detailed rules because it creates a robust structure within which statutory auditors have to justify their actions. It also provides the audit profession and its regulators with the flexibility to react promptly and effectively to new developments in business and in the audit environment. At the same time, it avoids the highly legalistic and rigid approach to what is and is not permitted which can arise in a rules-based regime. A principles-based approach can cater for the almost infinite variations in individual circumstances that arise in practice and in the different legal environments throughout the EU. Consequently, a principlesbased approach will better serve the needs of European capital markets, as well as those of SMEs.
\end{abstract}

The Sarbanes Oxley Act of 2002 imposed a prohibition on nine non audit services, measures aimed at improving audit independence. Section $201^{70}$ of the Act provides:

"It shall be "unlawful" for a registered public accounting firm to provide any non-audit service to an issuer contemporaneously with the audit, including: (1) bookkeeping or other services related to the accounting records or financial statements of the audit client; (2) financial information systems design and implementation; (3) appraisal or valuation services, fairness opinions, or contribution-in-kind reports; (4) actuarial services; (5) internal audit outsourcing services; (6) management functions or human resources; (7) broker or dealer, investment adviser, or investment banking services; (8) legal services and expert services unrelated to the audit; (9) any other service that the Board determines, by regulation, is impermissible. The Board may, on a case-by-case basis, exempt from these prohibitions any person, issuer, public accounting firm, or transaction, subject to review by the Commission."

In contrast to Sarbanes Oxley, the revised Eighth Council Directive ${ }^{71}$ and the 2006 Statutory Audit Directive adopt a principles based approach to regulation ${ }^{72}$. This is expressly stipulated under Chapter IV Article 22 paragraph 4 which states:

\footnotetext{
${ }^{68}$ See W Doralt and others, ‘ Auditors' Liability and its Impact on the European Financial Markets' (2008) 67

Cambridge Law Journal at page 62

${ }^{69}$ See paragraph 11 'COMMISSION RECOMMENDATION of 16 May 2002 Statutory Auditors' Independence in the EU: A Set of Fundamental Principles' <http://eurlex.europa.eu/LexUriServ/LexUriServ.do?uri=OJ:L:2002:191:0022:0057:EN:PDF<

${ }^{70}$ Services Outside The Scope Of Practice Of Auditors

${ }^{71}$ See C Strohm, United States and European Union Audit Independence Regulation: Implications for Regulators and Auditing Practice 2006 DUVat page 65;'Exploration of Non-Professional Ownership Structures
} 
4. In order to ensure confidence in the audit function and to ensure uniform application of paragraphs 1 and 2 of this

Article, the Commission may, in accordance with the procedure referred to in Article 48(2), adopt principlebased implementing measures concerning:

(a) the threats and safeguards referred to in paragraph 2;

(b) the situations in which the significance of the threats, as referred to in paragraph 2 , is such that the independence of the statutory auditor or audit firm is compromised;

(c) the cases of self-review and self-interest referred to in the second subparagraph of paragraph 2, in which statutory

audits may or may not be carried out.

Whereas Sarbanes Oxley outrightly prohibits the provision of stipulated non audit services, the 2006 Statutory Audit Directive leaves it to Member States to determine and decide on situations where the auditor's independence could be considered to have been compromised. Various academic literature and research results have indicated that SOX restrictions on non audit services may have been a step too far. ${ }^{73}$ The "unopposed political support" given to Sarbanes Oxley has received criticisms and calls for explanations as to why such support was given. Further, Brown et al state that a consideration of factors which would explain why "self- interested rule makers" may wish to enact governance rules which have little potential to improve financial market performance may constitute a worthwhile topic for purposes of future research. $^{74}$

\section{Conclusion}

A prohibition on the provision of specific non audit services by the major 4 audit firms whilst permitting mid tier audit firms and smaller audit firms to provide non audit services which would enable them to become more competitive, could serve a s a powerful tool in facilitating greater entry of currently "disadvantaged" audit firms into the audit market. Such a move would also foster a higher level of competition whilst ensuring that the level of audit quality $\mathrm{s}$ not undermined.

for Audit Firms International Organisation of Securities Commissions Sept 2009 at pages 4 and $5<$ http://www.cfainstitute.org/centre/topics/comment/2009/pdf/090225.pdf>

${ }^{72}$ The Recommendation issued by the Commission in 2002 on the independence of statutory auditors combines its broader safeguards with the principles based approach to independence and these include:

"the full disclosure, at least annually, of fees for audit and non-audit services, and a written declaration confirming independence, which must be made by the auditor to the audit client's governance body, for example a board of non-executive Directors or a supervisory board. Furthermore, all EU statutory audits should be subject to external quality assurance systems that require auditors to review compliance with ethical principles and rules, including independence rules, according to the Commission's existing Recommendation on "Quality Assurance for the statutory audit in the EU. See 'Auditing: Commission issues Recommendation on Independence of Statutory Auditors"

<http://europa.eu/rapid/pressReleasesAction.do?reference=IP/02/723\&format=HTML\&aged=1\&language=EN\& guiLanguage=en>

${ }^{73}$ See J Brown, D Falaschetti and M Orlando, ,Auditor Independence and the Quality of Information in Financial Disclosures: Evidence for Market Discipline vs Sarbanes-Oxley Proscriptions' 2009 forthcoming in the American Law and Economics Review at pages 1 and 31 of the article.

${ }^{74}$ Ibid at page 32 
The effectiveness of measures aimed at reducing market barriers to entry of audit markets, to an extent, depends on various factors such as the demand for audits in a particular jurisdiction. For example, efforts aimed at lowering market barriers/reducing audit concentration, namely low liability caps are likely to be more effective in certain jurisdictions than others depending on the level of demand for audit markets in these jurisdictions. Other proposals aimed at lowering market barriers also have their disadvantages. For example, the enactment of less complex or less rigid regulations, as previously highlighted under section four.

Whether the Sarbanes Oxley Act is functioning effectively as an antidote in addressing the issue of audit independence rather than providing necessary ingredients required for a potentially lethal cocktail whilst aggravating the level of audit quality remains to be seen. Hopefully the 2006 Statutory Audit Directive, in collaboration with efforts aimed at reducing barriers to entry in the international audit market, ensuring that competition is sustained and that the quality of audits are not undermined, will provide the much required assistance ( and promptly) to avert the impending consequences of the Sarbanes Oxley Act. 


\section{REFERENCES}

'APB issues a Consultation Paper on audit firms providing non-audit services to listed companies that they audit' < http://www.frc.org.uk/apb/press/pub2125.html>

Auditing: Commission issues Recommendation on independence of statutory auditors' < http://europa.eu/rapid/pressReleasesAction.do?reference=IP/02/723\&format=HTML\&aged=1 $\underline{\text { llanguage }=E N \& \text { guiLanguage }=\mathrm{en}>}$

Bigus J and Zimmerman R, 'Non Audit Fees, Market Leaders and Concentration in the German Audit Market: A Descriptive Analysis' (2008)International Journal of Auditing Vol 12 at page 174

Brown J, Falaschetti D and Orlando M, ,Auditor Independence and the Quality of Information in Financial Disclosures: Evidence for Market Discipline vs Sarbanes-Oxley Proscriptions' 2009 forthcoming in the American Law and Economics Review at pages 1 and 31 COMMISSION RECOMMENDATION of 16 May 2002 Statutory Auditors' Independence in the EU: A Set of Fundamental Principles'http://eurlex.europa.eu/LexUriServ/LexUriServ.do?uri=OJ:L:2002:191:0022:0057:EN:PDF

Chan P, Ezzamel M, and Gwilliam D, 'Determinants of audit fees for quoted U.K. companies' (1993) Journal of Business Finance \& Accounting, 20, pp. 765-786.

Consultation on Control Structures in Audit Firms and their Consequences on the Audit Market" at page $7<$

http://ec.europa.eu/internal_market/auditing/docs/market/consultation2008/summary_report_e $\underline{\text { n.pdf }>}$

Doralt W and others, 'Auditors' Liability and its Impact on the European Financial Markets' (2008) 67 Cambridge Law Journal at page 62

DIRECTIVE 2006/43/EC OF THE EUROPEAN PARLIAMENT AND OF THE COUNCIL of 17 May 2006 on statutory audits of annual accounts and consolidated accounts

Ezzamel M, Gwilliam DR and Holland KM, 'The Relationship between Categories of NonAudit Services and Audit Fees: Evidence from UK Companies' (2002) International Journal of Auditing (6) 13-35

Fourth Council Directive 78/660/EEC

Jensen MC and Meckling WH , 'Theory of the firm: managerial behaviour, agency costs and ownership structure' (1976) Journal of Financial Economics, 3, pp. 305-360.

Ojo M 'Proposals For a New Audit Liability Regime in Europe' and 'Limiting Audit Firms' Liability: A Step in the Right Direction? (Proposals For a New Audit Liability Regime in Europe Revisited) 
Ojo M 'The Role of the External Auditor in Bank Regulation and Supervision: A

Comparative Analysis between the UK, Germany, Italy and the US (2008) VDM

O'Sullivan N and Diacon SR, 'Impact of Ownership, Governance and Non Audit Services on Audit Fees: Evidence from the Insurance Industry'(2002) International Journal of Auditing Volume 6 at page 95

Quick R and Warming-Rasmussen B, 'Auditor Independence and the Provision of Non Audit Services: Perceptions by German Investors'(2009) International Journal of Auditing Volume 13

Seventh Council Directive 83/349/EEC

"Statutory Auditors' Independence in the EU: A Set of Fundamental Principles"< http://www.iasplus.com/resource/euaudit.pdf>

Strohm C, United States and European Union Audit Independence Regulation: Implications for Regulators and Auditing Practice 2006 DUV

Treasury Ninth Report, 'Banking Crisis: reforming corporate governance and pay in the City' May $2009<$

http://www.publications.parliament.uk/pa/cm200102/cmselect/cmtreasy/758/2070213.htm>

Welch I, "Should Cross Selling of Non Audit fees be Banned? FRC Consults on MPs Recommendation" 12 October 2009 